\title{
Vol. 1: The Excellence of Technical Vocational Education and Training (TVET) Institutions in Korea: Yeungjin College Case Study
}

\author{
Lan $\mathrm{Joo}^{1}$ \\ ${ }^{1}$ The World Bank, Washington D.C., USA \\ Correspondence: Lan Joo, The World Bank, Washington D.C., USA. Tel: 1-571-337-7117. E-mail: \\ lanjoolan@yahoo.com
}

Received: December 19, 2017

Accepted: January 31, $2018 \quad$ Online Published: June 28, 2018

doi:10.5539/ies.v11n7p136

URL: https://doi.org/10.5539/ies.v11n7p136

\begin{abstract}
To tackle the issue of skill shortages, many governments are restructuring their respective school systems into more demand-driven systems, which are expected to improve overall school outcomes and external efficiency. In order to assist TVET institutes and governments with the development of innovative methods to improve the outcomes, this study seeks to provide suggestions drawn from an in-depth case study of a successful TVET school. The study assessed whether or not the select school possesses four premise factors (competent teachers, relevant curricula, effective leadership, and school-industry linkages) and how these factors contribute to the improvement of the graduate employment rate. The selection criterion was the school's high graduate employment rate. The study gathered data via survey and interviews of both faculty and students. As for the survey, 693 out of 1,400 juniors and 23 out of 71 professors responded. The interviews were a face-to-face, one-on-one style with structured, open-ended questions. Ten students and 10 professors were interviewed separately in a closed room, and 60 minutes was allotted for each session. After coding the raw data, certain themes emerged. The findings suggest that Yeungjin College possesses all the stated premise factors, and the factors directly or indirectly influence the graduate employment rate via the enhancement of employability. Additionally, the most determining factor can be altered within different contexts (e.g. TVET policy, labor market conditions, social demands) and times.
\end{abstract}

Keywords: employability, leadership, school-industry linkages, skill shortages, TVET curricular, TVET policy, TVET school reform, TVET teachers

\section{Introduction}

\subsection{Purpose of the Study}

Over the past decades, East Asian countries have ranked among the fastest growing economies in the world; however, as their growth continues, the countries have been challenged with skills shortages and mismatching that has limited their economic growth. To tackle the issue of skill shortages, regional governments are restructuring their respective school systems into more demand-driven systems, which are expected to improve overall school outcomes and external efficiency. Simultaneously, many studies have investigated the relationship between school inputs and outcomes, although these studies are fragmented in such a manner that they examine respectively the effect of a single input on school outcomes reflecting their own study's purpose. School input areas include teachers, curricula, leadership, school-industry linkages, etc.

Rather than examining each area of input and its impact on outcomes, this study investigates if and how these inputs are likely to contribute to school success by examining two outstanding cases in Korea: Busan National Mechanical Technical High School (BMT) at the secondary level and Yeungjin College at the tertiary level. In this paper, study of the tertiary level is presented. By doing so, the study is expected to help individual institutions develop innovative methods to improve the internal and external efficiency of their programs as well as provide policy makers with empirical evidence which will be used to develop new policies that increase schools' responsiveness to industry demands.

\subsection{Literature Review}

\subsubsection{School Outcomes}

Empirical studies indicate that some degree of association between teachers, curricula, leadership, 
school-industry linkages and outcomes exist respectively, but because many scholars are more interested in examining these associations within the school system, they tend to examine student achievement as an outcome. On the other hand, Johansson and Adams (2004) examined outcomes occurring both within the school system as well as in the labor market. The authors asserted that the two efficiencies, internal and external, should be measured. The former measures the relationship between inputs and outputs and what occurs within the educational and training processes. The latter measures what happens to outputs of the training process in relation to economic and social requirements, also referred to as program relevance. Because the study's interest lies in TVET schools, whose role is to supply adequately skilled workers to industry, I will focus more so on external school outcomes. In this study, external outcomes will be measured via the graduate employment rate, because it shows how well graduates are absorbed into the labor market due to their increased employability via training and education.

\subsubsection{Employability}

Employability is not synonymous with the employment rate (Yorke, 2004, p. 410), but it does increase one's chances for gaining employment. Several authors define employability: for example, according to Pool and Sewell (2007), employability refers to "having a set of skills, knowledge, understanding and personal attributes that make a person more likely to choose and secure occupations in which they can be satisfied and successful" (p. 280). Hillage and Pollard (1998) stated further that employability is composed of four main elements, which include a person's employability assets (knowledge, skills and attitudes); career management skills (job search skills); job getting skills (CV effectiveness, work experience and interview techniques); and personal circumstances (family responsibilities and external factors).

\subsubsection{Teachers}

Various views exist regarding the effect of the teacher on student learning outcomes. Some scholars (Gerristen et al., 2016; Rockoff, 2004) argue that teacher experience has a strong effect, while others (Buddin \& Zamarro, 2009; Rivkin et al., 2005) state that observed teacher qualities, such as experience, indicate little effect on student outcomes. Furthermore, findings from Carnoy et al.'s (2016) study suggest that the effect of the teacher varies across students' backgrounds.

Concerning the former argument, Rockoff (2004) found that a one-standard-deviation increase in the quality of a teacher directly raises student test scores by roughly one-tenth of a standard deviation (pp. 247-2488), and among a teacher's quality characteristics, teaching experience positively impacts students test scores (p. 248). In addition, by using the longitudinal data of twins attending the same school in the Netherlands but with different teachers, Gerristen et al. (2016) found a direct effect from a teacher's experience on student achievement, especially among younger students. Data was pulled from the PRIMA survey, which was composed of 60,000 pupils in 600 schools. The authors used the data on students, parents, teachers and schools between 1994 and 2005.

While scholars generally agreed that the quality of a teacher is an important determinant in student achievement, studies' findings could not determine which particular characteristic of a teacher is impactful. For example, Rivkin et al. (2005) developed a value-added gains model with student's and school's fixed effects by using longitudinal data on the individual test scores of Texan students in grades three through six. Overall, the quality of teachers had a large effect on student achievement, but the effect size of experience and education was minimal. Buddin and Zamarro (2009) also utilized longitudinal student-level data from Los Angeles, California and found that teachers' licensure test scores, advanced degrees, and experience explain little about the variation in student learning outcomes.

Carnoy et al. (2016) further indicated the variation in the effect of teachers according to students' backgrounds. By using the TIMSS 2011 sample in Russia, the study found that the effect of teachers varies across students with different family backgrounds and different levels of past knowledge. The results indicated that, in opposition to students from high-income families with higher test scores, students from low-income families reflecting middle to lower test scores showed minimal impact from the effect of teachers on their individual scores.

\subsubsection{Curricula}

Many articles published in recent years have pointed out an overall industry skills shortage and its direct correlation to the role of schools in providing their students with relevant skills training.

For example, by examining the US, UK and Australia, Jackson (2009) asserted that businesses are dissatisfied with skills training in institutions of higher education, particularly in the areas of science, technology, engineering and mathematics (pp. 30-31).

In response to this skills shortage, other studies have discussed what type of skills should be taught in schools. For 
example, Sewell (2007) argued that the degree of specialty is important as evidenced by the UK Graduate Prospects Survey, which identified that one-third of graduate vacancies require subject-specific knowledge and skills (Jackson, 2009, p. 30). On the other hand, Harvey et al. (1997) stated that employers still point out the importance of generic skills in addition to job specific knowledge and skills (Pool \& Sewell, 2007, p. 282).

In general, scholars agreed that both aforementioned skill sets are important and should be included in curricula. For example, Bennett et al. (1999) proposed a course model that is composed of five elements, including both generic and specific skills, in order to improve graduate employability. The five elements are disciplinary content knowledge, disciplinary skills, workplace awareness, workplace experience, and generic skills (Pool \& Sewell, 2007, p. 282). Yorke (2004) also pointed out that a curriculum should contain a range of skills that are likely to help students in their future employment (p. 410). He further added that traditional approaches, such as lectures and seminars, might prove inadequate in the improvement of students' employability (p. 410).

\subsubsection{Leadership}

Dutta and Sahney (2015) assert that "successful schools possess an adept, strong and purposeful school leadership." (p. 941). Evidence suggests that school leadership affects outcome but it suggests that the effect of school leadership is rather indirect (Dutta \& Sahney, 2015, p. 942). For example, using a longitudinal study of 192 elementary schools in one state in the US over a four-year period, Hallinger and Heck (2010) found significant indirect effects of leadership on student achievement. The study examined the effects of collaborative leadership on student reading achievement by employing a mediated-effects model. The results indicated that leadership positively and indirectly affects students' learning outcomes via enhancement of the academic capacity in schools. Dutta and Sahney's (2015) study further supported leadership's indirect effect. Applying path modeling with cross-sectional survey data obtained from 306 secondary schools in New Delhi and Kolkata, India, the study found that the effects of principals' leadership on student achievement are mediated by teachers' job satisfaction. Teachers' job satisfaction directly effects student achievement significantly.

The importance of leadership in TVET schools has been emphasized in various TVET policy papers. For example, European Centre for the Development of Vocational Training: CEDEFOP (2011) summarized that Professionalization of VET teachers for the future (2004), published by the European Centre for the Development of Vocational Training, addressed the importance of training TVET school leaders in order to enhance their capability to manage human resources and motivate teachers to commit to school change. In line with the above paper, according to CEDEFOP, the OECD (2005)'s report, Teachers matter: Attracting, developing and retaining effective teachers, suggested strategies to improve the quality of school leadership which is believed to be a central element in the TVET national policy plan. Furthermore, CEDEFOP introduced leadership competencies described by Australian researchers. The competencies include "the ability to communicate a vision for the organization, build successful teams and inspire staff to make a commitment to change, as well as interpersonal skills, risk-taking, team-building and analytic and decision-making skills" (p. 32).

\subsubsection{School-Industry Linkages}

Ankrah et al., (2013) defined school-industry linkages as interactions between all parts of the higher educational system and industrializing economy (Ishengoma \& Vaaland, 2015). Additionally, Perkmann et al. (2013) view school-industry linkages as a form of inter-organizational collaboration, linking universities with other organizations, particularly firms (p. 424). According to Vaaland and Ishengoma (2015), Brimble and Doner (2007) describe the linkages more specifically by suggesting three types of linkages: training and education related activities; the provision of services and other consulting activities; and research-related activities. Vaaland and Ishengoma further explained these three types: Training and education-related activities include student field trips to partner companies and these companies' provision of career information to students (Suraweera,1985); a provision of work experience programs, such as internships (Ayarka et al., 2011); and the involvement of industrial practitioners in teaching (Suraweera, 1985, pp. 1019-1020).

Lin and Bozeman (2006) stated that students' exposure to industry during the school year supports an increase in students' future employment (Perkmann et al., 2013, p. 428). Empirical evidence supports the argument on the importance of students' exposure to industry. For example, by using survey data conducted in Tanzania, Ishengoma and Vaaland (2015) found that school-industry linkages, such as internships, industrial practitioners' teaching, and joint projects, raise the employability of students both directly and indirectly. The study's results indicated that among the linkage types, student internships showed the most effect. Data was constructed from the survey. The number of respondents was 404 which included students, faculty members and employees of 20 companies in the oil and gas and mining industries. 


\section{Methodology}

\subsection{Research Design}

The study suggests that four premise factors (competent teachers, relevant curricula, effective leadership, and school-industry linkages) are likely to contribute to enhancing school outcomes. Additionally, there are external factors influencing school success, called "Ecosystem factors", such as economic, social, and political conditions (Altbach \& Salmi, 2011). Hillage and Pollard (1998) also included an external factor among the four primary elements of employability. According to the authors, the external factors include the current opportunity level within the labor market.

The study questions (1) whether or not the selected case possesses the premise factors; (2) if so, how do these factors impact school outcomes; (3) which is the determinant that mostly contributes to the enhancement of school outcomes and in what context; and (4) how can the factors be strengthened.

The conceptual framework is a reverse examination of the relationship between outcomes (the graduate employment rate as an outcome indicator) and the premise factors by examining a high-performance school that retains high external efficiency. The logic is that if this high-performance school possesses these factors, then we could conclude that these factors are likely to raise the graduate employment rate. Therefore, the study could suggest that an excellent TVET institution produces the best school outcomes, because it (1) conserves competent teachers; (2) delivers relevant programs; (3) displays effective leadership; and (4) develops formal linkages with enterprise.

The study method is a case study. This method was used, initially, to allow for better in-depth analysis with the included explanatory-type research questions. Other reasons included the ability to trace the unit of analysis over time instead of by incidence i.e. allowing for study on how certain challenges were eliminated over time; the facility to prevent the investigator's manipulation of setting and actual events; as well as the fact that there were too many uncontrollable explanatory variables, like external factors.

\subsection{Case Selection}

I selected Yeungjin College, as it has reflected an outstanding employment rate among its graduates. In regard to the volume of employment, the data from the "Job Placement Statistics of Higher Education Institution Graduates", published by the Ministry of Education (MoE), indicates that Yeungjin reflected the highest graduate employment rate among colleges/universities between 2010 and 2014: 64.6 (2010), 78.2 (2011), 79.3 (2012), 77.0 (2013), and 78.9 (2014). This data is widely utilized, because it shows the actual number of employed graduates by calculating the number of graduates who registered for employee insurance within the country, as well as the number of graduates who gained employment overseas. This data is also a key index for the MoE to fund various university projects, such as the Education Competence Enhancement Project.

In addition to volume, Yeungjin has placed an emphasis on improving the quality of its graduates' job placement by helping them gain employment with prospective companies. For the last five years, the accumulated number of job placements in domestic major and overseas companies is 3,585 graduates. In regards to domestic companies, 841 graduates were employed at large companies in 2012, such as Samsung and LG. Overseas placements included 325 graduates that were employed at prospective companies in Japan, China, USA, Australia, Saudi Arabia, and New Zealand.

\subsection{Data Collection and Procedure}

Yeungjin's three majors (Mechanical Engineering; Electronic and Info-Communication; and Electronic Engineering) were selected for the purpose of data collection, because these majors are directly related to the manufacturing sector that has promoted Korea's rapid economic growth. As of 2015, the three majors retain 3,523 students, which is about $50 \%$ of the total number $(6,844)$ of Yeungjin students. Yeungjin has 315 faculty and staff members total (194 professors and 121 administrative workers). Among the 194 professors, the three schools above retain 71 . To increase its validity, the study collected data from multiple sources (Yeungjin, MoE websites, survey, and interview) and analyzed the perceptions of both students and professors.

\subsubsection{The Survey}

The survey was conducted with students and professors from the three aforementioned departments. It was conducted with juniors only; because freshmen have rather limited learning experiences with Yeungjin (Korean schools begin the first week in March, a month before this study was conducted). The total number of juniors enrolled in all three majors is 1,611, but 211 were on leave of absence due to military service primarily. Of the junior population, 693 out of 1,400 responded to the survey (approx. 50\% respondent rate). Twenty-three out of 71 
professors (both part-time and full-time) responded to the survey. The questionnaires for professors and students are shown in Appendix A and B.

\subsubsection{The Interview}

In order to acquire an in-depth analysis, the interviews included 10 students and 10 professors from the three aforementioned departments. The samples were randomly selected, but in order to conduct the interview, an agreement had to be achieved. The professors' queries covered the four areas (teachers, curricula, leadership, and linkages), while the students were questioned on teachers and curricula. Regarding the exclusion of leadership, students are not involved in school management, and in terms of the linkages exclusion, the students had not completed internships yet (internships only occur during the fall semester of the second year). The interviews were a face-to-face, one-on-one style with structured, open-ended questions (Appendix C and D). Ten students and 10 professors were interviewed separately in a closed room, and 60 minutes was allotted for each session.

All responses were dictated and recorded; then the raw data was coded. According to Coffey and Atkinson (1996), coding refers to condensing the bulk of data sets into analyzable units by creating categories with and from the data (p. 26). During the coding process, I created three levels of categories, namely general, intermediate, and specific (Coffey \& Atkinson, 1996, p. 48). Subsequently, several ideas and concepts emerged, as Coffey and Atkinson (1996) stated that codes, data categories, and concepts are related closely to one another (p. 27). These emerging ideas were presented in this paper as themes. After I drafted the study, I circulated it among the interviewees to obtain their consent on the findings.

\section{Results}

\subsection{Teachers}

\subsubsection{Professors' Perceptions}

Questioned on teacher recruitment, 35\% of the professors responded that "industry or work experience" is the most important qualification, and $91 \%$ of the professors responded that Yeungin's recruitment standards for professors are adequate to administer updated skills to students. In terms of in-service training, $91 \%$ of the professors responded that they completed in-service training although it is not mandatory. Among them, $67 \%$ attended a formal type of training, such as seminars, workshops and conferences.

During the interview, three themes emerged in Yeungjin's human resources: (1) recruitment of instructors with industry experience, (2) an advisory system that supports an individual student's employment, (3) performance-based payment and incentives.

First, based on its personnel recruitment standards, Yeungjin recruits instructors from industry, particularly those who hold mid- or high-level positions with large companies, via public contest. The recruitment standards also require at least a master's degree, but they do not require previous research experience. In fact, the professors can publish research papers after joining Yeungjin. The main purpose of this recruitment standard is to secure faculty members who are able to develop industrial demand-driven programs as well as strengthen school-industry cooperation. For the former, these instructors are able to respond to the changes in the labor market quickly and flexibly by continually updating their training materials; and if necessary, they can amend the programs. For the latter, these instructors have advantages in developing a Memorandum of Understanding (MoU) with companies by employing their own respective networks for assistance.

Second, in regards to an advisory system, one advisor is appointed to every 30-40 students within each major (this is decided in the second semester of the first year of school), and the advisor tracks his or her students until graduation. The advisor maintains the database on each student's academic history, and via a one-on-one meeting, he or she works closely with their respective student on developing career plans, providing company employment information and job opportunities. In addition to career counseling, they also support the students academically.

Third, the professors pointed out that the school's performance-based payment and incentives encourage them to produce better outcomes. Yeungjin focuses on outcome-based performance which is reflected in assessment, and an individual faculty member is rewarded according to this assessment. In addition, the professors receive incentives for their work, including developing a customized class, establishing a MoU with companies, and producing a high graduate employment rate.

\subsubsection{Students' Perceptions}

The results of the survey indicated the school's retention of adequate human resources. In regard to their professors' competence, $71 \%$ of the students reported that they are either satisfied (33\%) or very satisfied (38\%). 
Furthemore, $63 \%$ of the students received career counseling, and among them, 92\% reported that the counseling helped them navigate their career plans in order to secure a job.

During the interview, three themes emerged: faculty members' (1) industrial experience; (2) emphasis on employment; and (3) passion and concern for an individual student.

First, the students concurred that it is beneficial to have instructors with industry experience. Students' expectations for professors are that they should teach the most relevant skills to industry; stay abreast of all new scholarship/skills in their respective fields; maintain solid relationships with industry; offer students tips for employment preparation; find places for in-company training and jobs for students within their respective networks; and be able to develop training materials that reflect the most current skills. According to the students, their professors meet these expectations.

Second, the students agreed that Yeungjin's professors do not only teach but also place an emphasis on job placement. Whenever time allows - even during class - the professors provide tips for job preparation, such as interview skills. In addition, one-on-one meetings with their respective advisors are very helpful in solidifying their plans, e.g. deciding occupations, specific jobs, and future companies of employment. Their advisors also continually provide them with company-specific information and certificates necessary for applications to particular companies.

Third, the students said that their professors have a passion and concern for individual students. Specifically, professors support late learners by using personal time after class and on weekends. For example, one student stated that due to his previous studies at an academic high school, he did not have a great understanding of engineering during the first semester of his first year; however, his professors helped him improve his understanding via one-on-one meetings. Other students who studied at vocational high schools have received teacher support after class in both their physics and math classes. The students all agreed that the professors are willing to accommodate those who need further assistance. The professors also provide special weekend and vacation lectures.

Both professors and students shared their positive view of Yeungjin's human resources in the survey. Additionally, emerging themes were similar in both groups. Both emphasized the importance of a professor's industrial experience as well as their assistance with employment. The only emerging difference was that students also emphasized the importance of teachers' passions and concerns for individual students.

\subsection{Curricula}

\subsubsection{Professors' Perceptions}

The survey results support the school's delivery of relevant programs. Sixty-one percent of the professors strongly agree that the school's curricula (both academic and practical) reflect current industry demands. Fifty-seven percent of the professors strongly agree that the school offers high quality programs. However, 57\% of the professors also responded that students should take additional outside training to be readily employed.

During the interview, the professors pointed out the program's (1) customized, (2) flexible, and (3) well-balanced features that serve to achieve the school's successful outcomes.

First, Yeungjin consistently updates their programs to respond to rapid changes in industry. According to the professors, the school analyzes overall industrial demand first, and then conducts surveys with relevant companies. Next, the designed program is prepared for review by the Committee of Academic research management, and upon this initial approval, the program must undergo additional approval from three major companies in relevant fields. If the three companies approve the design, then the newly developed program is applicable to courses. In terms of textbooks, a responsible professor within each major works with a single representative from a relevant industry field. Next, the developed textbooks are sent to five randomly selected evaluators of industry via Yeungjin's library. After review and approval from the previous evaluators, the textbooks are ready for class usage. This revision and evaluation process of textbooks occurs every three to four years. In regards to training materials, the professors review and update them with representatives from respective relevant fields every two to three years.

Second, the professors agreed that Yeungjin's programs meet industry's needs via their customized program (Appendix E). The school selects certain companies for joint program development, and if the company agrees to participate, both the school and company proceeds with joint program development. Curricula updates are based upon any respective companies' needs. Furthermore, a class closes if there is low demand, and a new customized class is created if there is high industry demand. This opening and closing of classes is all based upon the assessment of respective companies' needs and requests. 
Third, the professors pointed out the school's balanced program of theory and practical training. The professors believe that a two-year college is not simply a training institute that focuses primarily on practice; but also needs to provide theory and basic knowledge of each field as well as the humanity within education. Theory is important, because it is a foundation that helps improve students' understanding of their respective fields; thereby, it enhances both their knowledge and skills. The professors also stated that the school does not offer any certificate-related courses. They believe that the students are solely responsible for obtaining certificates outside of school, and this explains why $57 \%$ of the professors responded that their students should take additional outside training. Simultaneously, they also believe that the school needs to provide adequate practical training that helps students prepare for future jobs.

\subsubsection{Students' Perceptions}

During the survey, $54 \%$ of the students responded that they are either satisfied (29\%) or very satisfied (25\%) with the program, and $45 \%$ responded that they receive more than ten hours of practical training per week. In regards to the question of whether or not they receive additional training, aside from in-school practical training, $38 \%$ said yes, and $46 \%$ of the students reported that they are planning to receive additional training after graduation. However, $69 \%$ of the students overall believe that the school is preparing them adequately to secure a job.

During the interview, the students agreed that the school delievers a relevant program via four characteristics of Yeungjin's program: (1) a well-established learning block; (2) updated skills training; (3) a focus on creativity; and (4) an absence of certificate-related courses.

First, they all agreed that the curricula is designed well enough to help them acquire a range of knowledge and skills from basic to specialized levels. During the first semester, all students study common subjects, then in the second semester of the first year, students are divided into sub-majors based on their interests and competence levels. Next, within each of their respective sub-majors, the students are separated into customized classes according to their respective competence levels. The remaining students, who are unable to attend customized classes, attend regular classes. In their second year, students obtain in-depth knowledge and skills in their relevant fields. The students reported that they are satisfied with this learning block.

Second, the students stated that they are obtaining the latest and most relevant skills. For instance, the school provides the latest Computer-aided design (CAD) program that is currently used in many major companies within their respective fields. The students said that the possession of this latest skill increases their self-confidence to the level of a highly demanded skilled worker in the current market. In addition, the students reported that the training materials developed by the professors are very helpful. The materials are substitutes that easily explain the utilization of machines, equipment, and computer programs. The materials reflect the current skills that alumni use in their work places.

Third, the students stated that their creativity has improved by taking the Capstone course. During the class, the students select a topic, develop an idea based on free debates and discussions, present their ideas, produce a product, conduct a survey for market value, and present their final product at graduation. The professors support them in finding necessary materials and share sound advice. According to the students, during the process, their ideas are developed, and most importantly, their self-confidence increases.

Finally, they agreed with their professors that the program should include theory, as the college is not a training institute designed primarily to help trainees obtain certificates. The students are satisfied with their practical training in the school; however, considering the importance of possessing particular certificates for certain jobs, they feel it is necessary to take additional training courses to obtain these certificates. This explains why $38 \%$ of students receive additional training even though the majority expressed their satisfaction with practical training offered by the school.

Within the survey, students supported the positive perception of professors regarding the delivery of relevant programs. Moreover, both the professors and students indicated the importance of additional training beyond school studies in order to acquire relevant certificates required by companies. However, they displayed slightly different concepts during the in-depth interviews. Professors emphasized the conversation around the school's demand-driven program, characterized as "customized, flexible, and well-balanced", while students emphasized their actual learning experiences during course study. The latter discrepancy could be attributed to the fact that students are more so interested in how they are learning in school.

\subsection{Leadership}

During the survey, in regards to leadership direction, $91 \%$ of the professors ( $48 \%$ strongly agree; $43 \%$ agree) 
responded that the school has a shared vision among their faculty members. Ninety-one percent of the professors either agree $(35 \%)$ or strongly agree $(56 \%)$ that the school leaders execute the school's guiding principles with clarity, and $92 \%$ (57\% strongly agree; $35 \%$ agree) responded that school leaders are consistent in their words and deeds. In terms of the capacity to deal with new challenges, $91 \%$ of the professors either agree $(30 \%)$ or strongly agree $(61 \%)$ that the school leaders envisage the future and consistently look for new and innovative products, processes, and services. Ninety-one percent of the professors either agree $(26 \%)$ or strongly agree $(65 \%)$ that the school has the capacity to deal with both anticipated and unexpected challenges/risks.

During the interview, three themes emerged: (1) leadership in school survival; (2) its continued preparation for future challenges; (3) and its concerns for human resources.

First, the professors pointed out that leadership is key to the school's survival. For example, leadership was key to the school's survival during the 1980s when there was low demands for two-year TVET colleges. These types of colleges were founded based upon the country's demands for mid-level technicians during the mid-1970s. However, beginning from the mid-1980s, two-year colleges faced a decline in student population. The factors contributing to these low demands for two-year colleges include changes in the economic structure that demanded more higher skilled workers; a change in the government's higher education policy that allowed four-year universities to accept more students; the establishment of in-house universities at large companies that provide specific skills; and increasing social demands for four-year diplomas. As a result, the training market became more competitive, and two-year colleges lost their competitiveness against both four-year and in-house universities. To overcome these challenges, with strong leadership, the school revamped their entire school system as follows:

Initially, Yeungjin amended their management system to coordinate the efforts of all faculty members to realize the school's single objective of maintaining an adequate number of competent students by utilizing financial and human resources efficiently and effectively. Next, the teacher recruitment policy was updated in order to replace academic-based professors with industry-experienced professors. Via public contest, the school began recruiting new professors who held mid- to high-level positions at large companies. With this newly appointed labor in place, the school reformed the curricula from supply to demand-driven via strengthening school-industry cooperation. Management understood that providing a demand-driven program was the key to success in the training market as most schools at that time provided supply-driven courses and failed to meet industrial demands. In order to develop demand-driven curricula, professors in each major conducted a series of surveys and interviews with specialists of companies and developed competence-based programs based on their responses. School-industry cooperation was strengthened by utilizing the professors' networks and participating in various government projects that supported Small and Medium Enterprises (SMEs).

Second, even after the initial re-haul, school leaders continually prepare for the next challenge, which is a decrease in the number of school-age students due to the rapid aging process in Korea. To overcome this challenge, Yeungin has invested in school advertisements since 1995; in fact, one faculty member stated that even though advertising has now become the norm, during the 1990s, most schools did not feel self-advertisement was necessary. Yeungjin was the first college that advertised itself.

Third, the professors agreed that Yeungjin's leadership makes faculty members feel a sense of ownership and stronger connection to the school. For example, during stages of difficulty, Yeungjin needed to establish its identity as a two-year TVET College in order to survive in the training market. The goal of retaining an adequate population of competent students and high graduate employment was established and shared by all faculty members. This sense of ownership encouraged faculty members to strive to achieve the school's goals by visiting high schools to attract students, developing a customized program and training materials, and establishing a MoU with companies.

\subsection{School-Industry Linkages}

The professors' survey reflected that $100 \%$ believe that a school should build a formal partnership with companies and that Yeungjin has built a successful partnership with companies in order to enhance the graduate employment rate.

During the in-depth interviews, the professors' responses paralleled the survey results by reflecting that Yeungjin has a well-established formal school-industry linkage via a MoU, and this linkage benefits both the school and the companies. The professors assessed three areas of cooperation: cooperation in resources, developing programs, and management. Another theme emerged during the interview, the importance of participation in government-led projects in order to expand cooperation.

\subsubsection{Areas of Cooperation: Resources, Programming, and Management}


Concerning resources, the school has actively worked with SMEs by sharing both facilities and human resources. Yeungjin's seven Centers support local SMEs in various ways, from product design/development, prototype production, safety testing, production, to marketing. The school provides expensive equipment/machinery that SMEs cannot retain as well as technical assistance. Simultaneously, companies provide in-company training for students and attend the Committee Meeting. Furthermore, via working with SMEs, professors obtain information on employment and industrial demand, as well as company-specific information.

As for program development, the professors of each major and representatives from 10 relevant companies hold a bi-annual meeting to develop curricula and training materials together. During that meeting, the school receives the companies' skills-demands in relevant fields. Particularly, for the customized classes that are created based upon the company's request, the professors and the representatives from that specific company develop curricula together, and $50 \%$ of the program is required by the company.

However, all professors disagree with the idea of cooperation in management, believing that not even the establishment of a management committee would work, because its members would lack a strong sense of ownership and policies would be inconsistent.

\subsubsection{Expanding Cooperation via Government-Funded Projects}

Yeungjin's participation in government-funded projects enables the school to expand its cooperation with companies. For example, the school participates in the Ministry of Commerce, Industry, and Energy (MoCIE)-funded project that supports the SMEs in the region with the creation of a SMEs consortium. One particular professor also described how he submitted a proposal to one of the government-funded projects. His proposal on "cultivating skilled workers for the energy sector" aims to supply skilled workers to the companies in the stated strategic sector as well as increase youth employment via scholarship provided by this project. Since it appeared to be beneficial to both sides, the professor was able to convince 27 energy companies to co-develop the proposal, and a MoU with each company was developed. The professors agreed that it is important to keep pace with government policy on school-industry linkage and find opportunities within this policy.

\section{Discussion and Conclusion}

\subsection{Research Question Responses}

\subsubsection{Testing the First Research Question - Does the select school possess these premise factors?}

The findings strongly support that Yeungjin conserves competent teachers, delivers relevant programs, displays excellent leadership, and establishes formal school-industry linkages.

\subsubsection{Testing the Second Research Question - Do the above factors influence school outcomes; and if so, how?}

First, the findings illustrate that teachers do influence school outcomes. Yeungjin's professors directly influence employment by finding jobs for their students within their respective networks. The professors also indirectly influence employment via the enhancement of students' employability: students are able to improve their overall employability, because professors equipped with industry experience are able to design industrial demand-driven programs, teach relevant skills, and develop training materials that reflect the latest skills.

Second, Yeungjin's relevant programs indirectly increase the graduate employment rate via the enhancement of students' employability. As many scholars agreed that both generic and specific skills are important and should be included in the TVET school curricular (Yorke 2004), Yeungjin provides both general and specific programs: the students obtain generic skills during their first year and obtain job specific skills during their second year via customized classes. In addition, courses, textbooks, and training materials are continually reviewed and updated to meet industry needs.

Third, leadership influences school outcomes, and as the previous studies (Dutta \& Sahney, 2015; Hallinger \& Heck, 2010) indicated, its impact is rather indirect. Yeungjin's leadership increases the graduate employment rate via the provision of overall direction (a teacher recruitment policy, relevant programs, and school-industry linkages). Furthermore, in line with the previous authors' (Australia, 2007; ECDVT, 2004; OECD, 2005) suggested components of leadership competence, the findings show that Yeungjin's leader has ability to manage resources efficiently and motivate teachers to make a commitment to school change. The findings also reveal that Yeungjin's leader encourages maximum output with a strong sense of ownership from faculty as they work to achieve shared goals and prepares the school for future challenges.

Fourth, school-industry linkages directly and indirectly influence school outcomes. The linkages directly influence the outcomes: the students in Yeungjin are likely to be hired by companies with a formal linkage, because some companies hire the students via customized classes that are pre-arranged. The school receives an 
initial recruitment request from these companies, and then the professors recommend an individual student after matching the company's requests with an individual student's skills, level of competency, and interest. The linkages also indirectly influence the employment rate via the enhancement of students' employability. As Lin and Bozeman (2006) stated that students' exposure to industry during the school year supports an increase in students' future employment, Yeungin's students improve their employability by participating in internships and the school's joint projects with SMEs. The latter finding is also consistent with Ishengoma and Vaaland's (2015) finding that school-industry linkages, such as internships and joint projects, raise the employability of students.

4.1.3 Testing the Third Research Question-Which Determinant Mostly Contributes to the Enhancement of School Outcomes and in What Context?

The findings suggest that a key determining factor is alterable within different contexts and times.

During the 1980s, leadership was the key factor determining outcomes due to changes in external factors, such as occupational structure, the government's policy on higher education, and social demands. Like other two-year colleges, Yeungjin faced the major challenge of a decreasing enrollment rate. Moreover, as a private institute, (the majority of Korea's two-year colleges are privately owned but overseen by the MoE), it had to overcome the challenges on its own. According to faculty members, these challenges were met with and overcome by strong leadership. More specifically, in response to the challenges, the President and professors collaborated on several ideas; and after establishing a reform agenda, the President introduced school policy reformation as a whole. The school amended the management system to use resources more efficiently and updated the teacher recruitment policy in order to recruit professors with industry-experience who had a direct hand in the development of customized programs.

On the other hand, school-industry linkages have become a key determining factor in the present-day. In fact, there had been no concrete concept of school-industry cooperation when schools were not concerned about their students' employment due to fast economic growth. However, with high youth employment and slow economic growth, employment has become a major concern for the government, TVET schools, and individual students. By emphasizing employment, the government provides financial support to a school based upon a high graduate employment rate. The graduate employment rate also determines the pool of applicants, because applicants regard a school with a high employment rate, especially a high rate within large companies and the public sector, as a top-ranking school. Given this external condition, Yeungjin has to move towards demand-driven programming, specifically pre-arranged customized classes that are directly linked to employment with a specific company or companies. School-industry cooperation has become the key to developing such demand-driven programs and customized classes.

\subsection{Lessons Learned}

First, schools should reconsider their teacher recruitment standards and payment schemes that can directly affect school outcomes. It is highly recommended that post-secondary TVET schools hire instructors with industry experience, and these instructors should be paid based on their outputs and performance. The Yeungjin case clearly shows that the first step in the transformation from supply-driven to demand-driven education is reforming the teacher recruitment policy. Moreover, because they are paid and rewarded based upon performance and outcomes, the instructors are highly encouraged to focus on their output performance, especially the job placement of responsible students.

Second, teachers should emphasize employment in addition to teaching. The teachers' role should not be limited to just instruction in TVET schools. Teachers should not only teach students relevant skills and knowledge but also assist them in finding jobs. The findings from Yeungjin's case indicate that professors' extensive employment services directly affect an increase in the graduate employment rate. For example, instructors consistently provide interview tips during classes. Advisors, assigned to individual classes, work closely with their respective students in career development; provision of company employment information and job opportunities; job acquisition strategies; and the provision of recommendations to companies by matching the student's level of competency and interest with company requests. In addition, instructors are encouraged to document all employment services (assistance) provided to an individual student by maintaining a database.

Third, leadership is key to school survival in the face of external challenges. When a school faces external challenges, leadership plays a key role in overcoming these challenges. In Yeungjin's case, guided by strong leadership, the school was able to undergo a complete reformation, because the school's President strongly supported the professors' suggestions on transforming the program from supply-driven to demand-driven, and the professors devoted themselves to this reform effort as they felt a sense of ownership and unity. Furthermore, under leadership that provides overall direction, management is able to utilize resources efficiently in order to achieve set 
goals and encourage faculty members to achieve maximum output.

Fourth, schools should expand school-industry cooperation. With high youth employment and slow economic growth, it is inevitable that TVET schools must discover a way of improving their students' employability and competiveness in the labor market. In order to do so, schools should jointly develop demand-driven education and training with industry, and well-established school-industry cooperation is a pre-requisite for developing such demand-driven programs. Yeungjin's case clearly shows that its well-established formal linkages with companies enable the school to deliver not only relevant programs but also customized programs that meet the specific needs of a particular company or companies.

Fifth, post-secondary level TVET institutions should locate a market niche within their field of advantage. The goal of post-secondary TVET institutions is to cultivate proficient mid-level skilled workers for industry; but oftentimes, graduates have limited positions in the labor market due to their unclear role between low- and high-level skilled jobs, education inflation, and a brief training duration compared to a lengthier stay at a four-year University. Low-level skilled workers in a production line and high-level skilled workers in research, planning, and management mainly drive the manufacturing sector. In addition, an increase in the number of job seekers from four-year universities has created education inflation; oftentimes, these graduates occupy mid-level positions. Therefore, it is recommended that two-year TVET institutions should cultivate mid-level skilled workers with special skills in their field of advantage. As the case illustrates, Yeungjin selects its field of advantage from the government's select strategic sectors within the region. In addition, re-establishing the role of mid-level skilled workers who are bridging research-based production and actual production is necessary in the labor market to increase their advantage.

Lastly, the government should develop TVET policy that links TVET providers, SMEs, and local government under the goal of local economic growth and utilize funds to enhance TVET school outcomes. As the Yeungjin case illustrates, school-industry cooperation works best if it is a part of the regional economic growth policy. Utilizing their select strategic sectors within the region, the government should connect schools, local companies, and the local government; then, within this framework, the schools would provide technical assistance and skilled workers to the SMEs and train their employees; in turn, the SMEs would hire the graduates. Additionally, each government agency should emphasize its own area to avoid any work overlap: for example, the MoE would fund TVET schools to ease students' school-to-work transition via industry cooperation and the MoCIE would fund SMEs to increase their capacity in the local economy via cooperation with the schools. This concord policy connecting TVET, SMEs, and the local economy could benefit both the schools and the SMEs, which would ultimately lead to an increase in local economic growth.

\subsection{Study Limitations}

I acknowledge that the study has methodological limitations, such as a self-selection bias during the data collection. It could be possible that those professors and students who view Yeungjin more positively were more responsive to the study. Additionally, the study could be cited for a limitation in generalizability. However, the case was conducted under the Multiple-Case Study Model (Appendix F) that was adopted from Yin's (2003) concept of replication logic and analytical generalizability: "Replication logic" implies that the same method is replicated across the cases, and if the findings support our theoretical proposition, then our findings will be both compelling and robust. "Analytical generalization" occurs when inference exists between theoretical propositions and the empirical results of the case study (p. 37). So far, the two case studies (Yeungjin and BMT) under this model support the theoretical proposition. If we conduct more studies by replicating the same method and are able to arrive at common conclusions from the cases, even though the contexts of the cases differ to some extent, the findings could be generalizable. After all, despite the limitations, the findings and suggestions drawn from the study could still be useful to TVET institutions and governments that have undergone a reform process to overcome the issue of skills shortages.

\section{References}

Altbach, P. G., \& Salmi, J. (2011). Introduction. In P. G. Altbach, \& J. Salmi (Eds.), The Road to Academic Excellence: The Making of World-Class Research Universities (pp. 1-8). Washington D.C.: World Bank. https://doi.org/10.1596/9780821388051_INTRO

Buddin, R., \& Zamarro, G. (2009). Teacher qualifications and student achievement in urban elementary schools. Journal of Urban Economics, 66(2009), 103-115. https://doi.org/10.1016/j.jue.2009.05.001

Carnoy, M., Khavenson, T., Loyalka, P., Schmidt, W. H., \& Zakharov, A. (2016). Revisiting the relationship between international assessment outcomes and educational production: Evidence from a longitudinal 
PISA-TIMSS sample. American Educational Research Journal, 53(4), 1054-1085. https://doi.org/10.3102/0002831216653180

Cedefop. (2011). Exploring leadership in vocational education and training (Working Paper No. 13). Retrieved from http://www.cedefop.europa.eu/en/publications-and-resources/publications/6113

Coffey, A., \& Atkinson P. (1996). Making Sense of Qualitative Data. Thousand Oaks: Sage Publications.

Dutta, V., \& Sahney, S. (2015). School leadership and its impact on student achievement: The mediating role of school climate and teacher job satisfaction. International Journal of Educational Management, 30(6), 941-958. https://doi.org/10.1108/IJEM-12-2014-0170

Gerristen, S., Plug, E., \& Webbink, D. (2016). Teacher quality and student achievement: Evidence from a sample of Dutch twins. Journal of Applied Econometrics, 32, 643-660. https://doi.org/10.1002/jae.2539

Hallinger, P., \& Heck. R. H. (2010). Leadership for learning: Does collaborative leadership make a difference in school improvement? Educational Management Administration \& Leadership, 38(6), 654-678. https://doi.org/10.1177/1741143210379060

Hillage, J., \& Pollard, E. (1998). Employability: Developing a framework for policy analysis. London: Department for Education and Employment. Retrieved from http://hdl.voced.edu.au/10707/10058

Ishengoma, E., \& Vaaland, T. I. (2015). Can university-industry linkages stimulate student employability? Education and Training, 58(1), 18-44. https://doi.org/10.1108/ET-11-2014-0137

Jackson, D. (2009). An International profile of industry-relevant competencies and skill gaps in modern graduates. International Journal of Management Education, 8(3), 29-58. https://doi.org/10.3794/ijme.83.288

Johanson, R. K., \& Adams. R. V. (2004). Skills development in Sub-Saharan Africa. Washington D.C.: World Bank. https://doi.org/10.1596/0-8213-5680-1

Nettles, S. M., \& Herrington, C. (2006). Revisiting the importance of the direct effects of school leadership on student achievement: The implications for school improvement policy. Peabody Journal of Education, 82(4), 724-736. https://doi.org/10.1080/01619560701603239

Perkmann, M. et al. (2013). Academic engagement and commercialisation: A review of the literature on $\begin{array}{llll}\text { university-industry relations. } & \text { Research }\end{array}$ https://doi.org/10.1016/j.respol.2012.09.007

Pool, L. D., \& Sewell, P. (2007). The key to employability: Developing a practical model of graduate employability. Education and Training, 49(4), 277-289. https://doi.org/10.1108/00400910710754435

Rivkin, S. G., Hanushek, E. A., \& Kain, J. F. (2005). Teachers, schools and academic achievement. Econometrica, 73(2), 417-458. https://doi.org/10.1111/j.1468-0262.2005.00584.x

Rockoff, J. E. (2004). The impact of individual teachers on student achievement: Evidence from panel data. American Economic Review, 94(2), 247-252. https://doi.org/10.1257/0002828041302244

Vaaland, T. I., \& Ishengoma, E. (2015). University-industry linkages in developing countries: Perceived effect on innovation. Education and Training, 58(9), 1014-1040. https://doi.org/10.1108/ET-07-2015-0067

Yin, R. K. (2003). Case Study Research: Design and Methods (3rd ed.). Thousand Oaks: Sage Publications.

Yorke, M. (2004). Employability in the undergraduate curriculum: Some student perspectives. European Journal of Education, 39(4), 408-427. https://doi.org/10.1111/j.1465-3435.2004.00194.x

\section{Notes}

Note 1. This article was modified from the original case study Case study of an excellent TVET institution: Yeungiin Junior College, Daegu, South Korea (2016), conducted at the World Bank with the support of the Korea-World Bank Partnership Facility Grant to promote job creation and skills development in the East Asia region

Note 2. Two cases were selected under the Multiple-Case Study Model: Busan National Mechanical Technical High school and Yeungjin College that have supplied workers to the manufacturing sector, which has been a key engine in Korea's economic growth. 


\section{Appendix A}

\section{Survey Questionnaire for Teachers}

1. Do you think the school provides adequate financial support to your students?

1) $\mathrm{Yes}=>$ go to $\mathrm{Q} 1.1$

2) No

1.1 Do you think providing financial support plays a primary role in attracting talented students?
1) Yes
2) No

2. Please respond to the following phrases utilizing a response from the ratings below. Select the rating that most clearly and honestly reflects your opinion:
a. School building conditions, including the practical training facility
b. Equipment maintenance
c. Retaining full and updated equipment

\begin{tabular}{|l|l|l|l|l|}
\hline Excellent & Good & Fair & Bad & Poor \\
\hline
\end{tabular}

3. Does the school have a support system to assist students with their career plans (e.g. a job service center)?

1) $\mathrm{Yes}=>$ go to $\mathrm{Q} 3.1$

2) No

3.1. Please rate the existing support system:

\begin{tabular}{|l|l|l|l|l|}
\hline Excellent & Good & Fair & Bad & Poor \\
\hline
\end{tabular}

4. Do you assist students in career development?
1) Yes
2) No

5. In your opinion, which is the most important criterion in recruitment of a competent teacher?

1) Minimum academic qualifications (certificates, diplomas, and degrees)

2) Minimum years of industry or work experience

3) Minimum years of teaching experience

4) Other

6. Do you think that your school's recruitment standards for teachers are adequate enough to select competent teachers who will improve the employability of the student population?
1) Yes
2) $\quad$ No $=>$ go to $Q 6.1$

6.1 Please explain why the standards are not adequate

7. Did you complete in-service training?
1) Yes $=>$ go to Q7.1-7.3
2) No

7.1. Select type(s) of training.

1)

4)
Seminars, workshops, and conferences

Formal courses

Formal mentoring and leadership coaching

Other

7.2. How many hours per year did you complete?
1) Less than 10
2) $10-15$ 
3) $16-20$

4) Greater than 20

7.3. Did you receive the training from companies contracted by the school?

1) Yes

2) No

8. Are you a competent teacher; do you possess the required teaching skills set?

1) Yes

2) $\mathrm{No}=>$ go to Q.8.1

8.1. What missing skills would increase your competence?

1) More academic knowledge

2) More practical training

3) More work experience

4) More teaching experience

5) Other

9. Please rate your relationship with your students:

\begin{tabular}{|l|l|l|l|l|}
\hline Excellent & Good & Fair & Bad & Poor \\
\hline
\end{tabular}

10. All in all, does the school have adequate financial and human resources to produce competitive school outcomes (e.g. the graduate employment rate)?
1) Yes
2) No

11. Please respond to the following statements utilizing a response from the ratings below. Select the rating that most clearly and honestly reflects your opinion:
a. The school curriculum (both academic and practical) reflects current industry demands.
b. The school offers high quality programs (both academic and practical programs).
c. My students need to take additional outside training to be employed.
d. My students enjoy their studies.
e. My students are highly competent.

\begin{tabular}{|l|l|l|l|l|}
\hline Strongly Agree & Agree & $\begin{array}{l}\text { Neither Agree nor } \\
\text { Disagree }\end{array}$ & Disagree & Strongly Disagree \\
\hline
\end{tabular}

12. Does the school offer academic programs to students who want to continue their education/pursue an advance degree?

1) $\mathrm{Yes}=>$ go to $\mathrm{Q} 12.1$

2) No

12.1. Do you think this program helps students advance to higher education?

1) Yes

2) No

13. All in all, does the school provide relevant teaching programs (including practical training) to produce competitive school outcomes (e.g. the graduate employment rate)?
3) Yes

4) No

14. Please respond to the following statements utilizing a response from the ratings below. Select the rating that most clearly and honestly reflects your opinion:

a. My school leaders have consistent school policies. 
b. My school leaders execute the school's guiding principles with clarity.

c. My school leaders are consistent about their words and deeds.

d. My school leaders envisage the future and consistently look for new and innovative products, processes, and services.

e. My school leaders encourage collaboration by building trust among faculty members.

f. My school leaders encourage self-determination and the developing competence of teachers.

g. My school leaders recognize my contribution by showing appreciation.

h. The school has a shared vision among their faculty and staff.

i. The school has the capacity to deal with both anticipated and unexpected challenges/risks.

j. The school is attracting highly competent students.

\begin{tabular}{|l|l|l|l|l|}
\hline Strongly agree & Agree & $\begin{array}{l}\text { Neither agree nor } \\
\text { disagree }\end{array}$ & disagree & Strongly disagree \\
\hline
\end{tabular}

15. Please rate the relationship
a. between you and the principal
b. between you and other teachers

\begin{tabular}{|l|l|l|l|l|}
\hline Excellent & Good & Fair & Bad & Poor \\
\hline
\end{tabular}

16. Do you believe that a school should build a formal partnership with companies?

1) Yes $=>$ go to Q16.1

2) No

16.1. Please explain why

17. If your school does not have a formal partnership, what barriers will the school encounter in forming the partnership?

1) The school is not interested in a formal linkage.

2) The school desires a linkage but lacks the capacity.

3) The companies are not interested.

4) Other

18. Do you believe that your school has built a successful partnership with companies in order to enhance school outcomes e.g. graduate employment rate?
1) Yes
2) No

19. To what degree has the government's TVET policies impacted your school's governance and policies?
1) All
2) Most
3) Some
4) None

20. Do you think Leadership at the National Level has consistent policies?
1) Yes
2) No

21. Do you think the government adequately articulates the policy on TVET collaboration (e.g. collaboration type, building methods, students' rights) and develops laws for this?

1) Yes 
2) $\mathrm{No}$

22. Do you think government financial mechanisms (e.g. incentives) help enhance school performance?

1) Yes

2) $\mathrm{No}$

23. Practically speaking, are your students readily able to advance their education e.g. from a community college to a four-year university?

1) Yes

2) $\mathrm{No}$

(C) Copyright 2016 by Lan Joo

\section{Appendix B}

\section{Survey Questionnaire for Students}

1. Why did you select the technical or vocational track?
1) Lack of financial support from parents
2) Low school achievement (test scores, GPA)
3) Preference to be employed after graduation
4) Parents' advice
5) Teacher's advice
6) Other

2. Why did you select this particular school?

1) My test scores and GPA

2) Personal interest

3) School's high graduate employment rate

4) Parents' advice

5) Teacher's advice

6) other

3. Do you have any certifications?

1) $\mathrm{Yes}=>$ go to $\mathrm{Q} 3.1$

2) No

3-1. How many certifications do you have?

4. Upon graduation, do you plan to pursue an advanced degree?

1) $\mathrm{Yes}=>$ go to $\mathrm{Q} 4.1$

2) No

4.1. Select desired level.

1) 4-year university

2) Graduate school

5. Upon graduation, do you plan to find a job?

1) Yes $=>$ go to Q5.1 -5.3

2) No

5.1 What size companies interest you?

1) Large company

2) Upper middle size company

3) Small and middle size company

5.2 What position level are you seeking?

1)Entry level

2)Low level skilled position

3)Middle level skilled position

4)High level skilled position

5.3 What is your expected salary? (USD)
1) Less than 1,000
2) $1,000-1,500$ 
3) $1,500-2,000$

4) Greater than 2,000

6. Please respond to the following phrases utilizing a response from the ratings below. Select the rating that most clearly and honestly reflects your opinion:
a. Classroom conditions
b. Computer labs/Computer access
c. Library
d. Recreation facilities
e. Practical training resources (facilities, equipment, machines, etc)
f. School programs (curricular and after school programs)
g. Career counseling
h. Teachers
i. General school life

\begin{tabular}{|l|l|l|l|l|}
\hline Very dissatisfied & Dissatisfied & $\begin{array}{l}\text { Neither satisfied nor } \\
\text { dissatisfied }\end{array}$ & Satisfied & Very satisfied \\
\hline
\end{tabular}

7. To what extent does a scholarship and/or any other financial support cover your course fees, residential costs, academic materials, etc.?
1) All
2) Most
3) Some
4) None

8. Do you receive career counseling?

1) $\mathrm{Yes}=>$ go to $Q 8.1$

2) $\mathrm{No}$

8.1 Is the counseling helping you navigate your career plans?
1) Yes
2) No

9. How many hours per week do you receive practical training at school?

1) Less than 10

2) $11-15$

3) $16-20$

4) More than 20

10. Do you think the school is preparing you adequately, skill-wise, to find a job?
1) Yes
2) $\quad$ No $=>$ go to Q10.1 and 10.2

10.1. Did you receive additional training, aside from in-school practical training?

1) $\mathrm{Yes}=>$ go to Q10.1.1

2) $\mathrm{No}$

10.1.1. How many hours per week do you train?
1) Less than 10
2) $10-15$
3) $16-20$
4) Greater than 20

10.2 Are you planning to receive additional training from a training institute after graduation?
1) Yes
2) No

(C) Copyright 2016 by Lan Joo 


\section{Appendix C}

\section{Interview Questions for Teachers}

1. Define "an excellent school".

2. In your opinion, what factors are attributed to your defined "excellent school"? How and why do they impact school outcomes, e.g. graduate employment rates?

3. Do you believe that your school has adequate resources (both financial and human) to enhance the employability of your students?

4. Do you believe that your school's resources (both financial and human) are efficiently utilized?

5. Do you believe that the school provides the most relevant and updated skills to enhance student employability?

6. Do you believe that your school is a well-managed school in terms of leadership and governance?

7. Do you believe that your school has strong enterprise partnerships in the areas of resources, teaching, and management?

8. Among the previous four factors, which factor had the highest impact on the success of schools (high employment rates of your students)? Provide an example within a specific context and time.

9. Based on personal experience, what are your suggestions on how to improve your identified factor?

10. How has your school successfully overcome both internal and external challenges? Provide an example within a specific context and time.

11. In your opinion, to what degree has the government's TVET policies impacted your school's governance and policies? Explain how.

(C) Copyright 2016 by Lan Joo

\section{Appendix D}

\section{Interview Questions for Students}

1. Why did you select this particular school? What were your expectations?

2. Are you satisfied (or dissatisfied) with your choice of this school? Please provide details in regards to the curriculum, facilities, teachers, etc.

3. Do you believe that your school is a top performing institution? Please explain why/why not.

4. Upon graduation, are you planning to pursue higher education or enter the labor market? Explain your decision.

5. In regards to career, what desired level do you aspire to secure on hire?

6. Do you think it is necessary to earn a university diploma to acquire this desired job?

7. Do you think the school provides adequate practical training in order to secure a job? If yes, please describe. If not, what are the primary challenges?

8. Do you believe that your school is helping you build your future career plans? Who helps you the most? How do they help you?

9. Do you think the school stimulates and supports your creative development? If so, please describe any existing programs and how they stimulate your creativity. If not, what are the primary challenges?

(C) Copyright 2016 by Lan Joo

\section{Appendix E}

\section{Customized Program}

The school receives requests from select companies to supply a certain number of skilled workers and then develops courses and curricula jointly to meet their requests. Students are expected to be hired by these companies upon graduation since they have acquired company-specific skills in addition to transferable, basic technical skills 


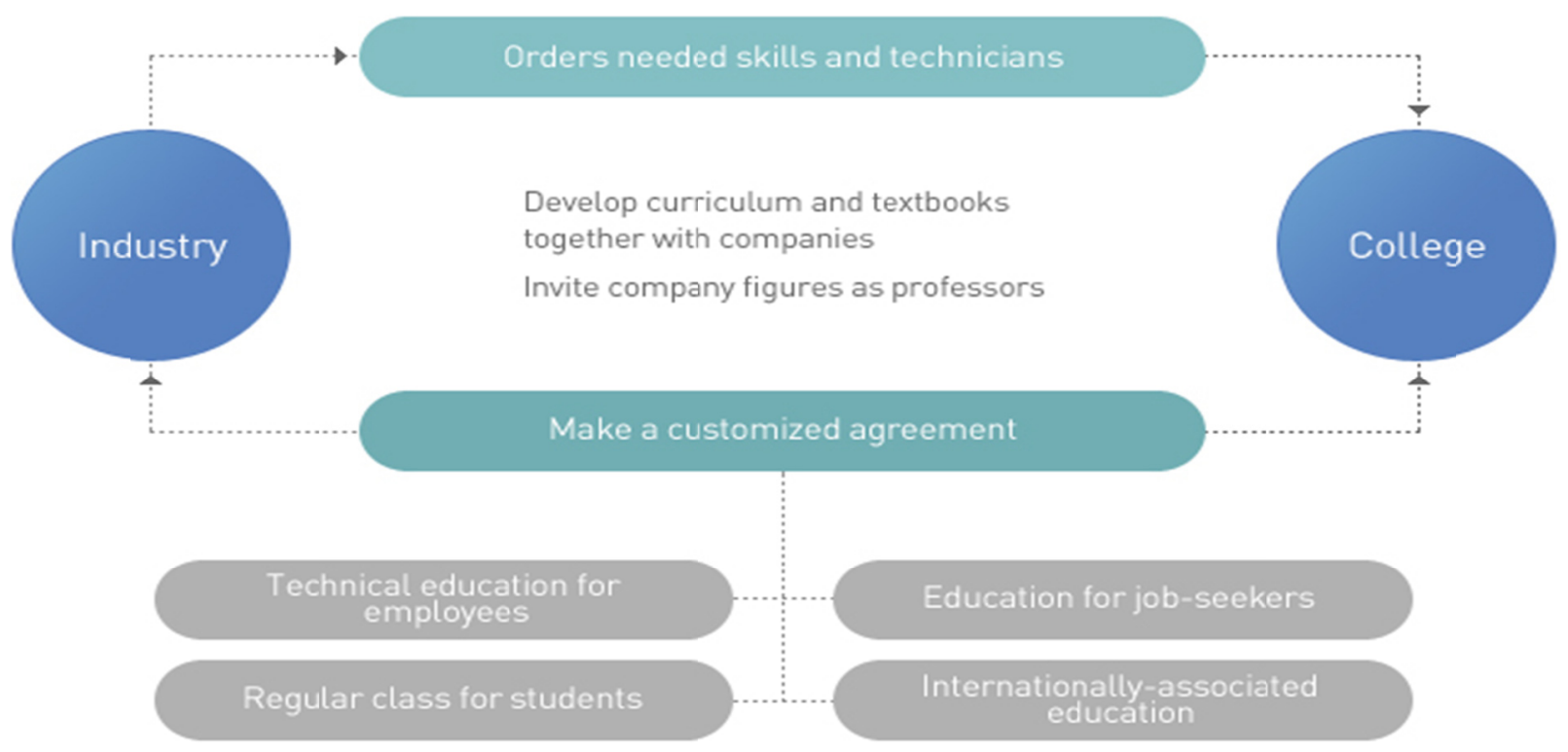

Source: Yeungjin College, http://www.yjc.ac.kr/CmsHome/MainDefault.jsp

\section{Appendix F}

\section{Multiple-Case study Design}

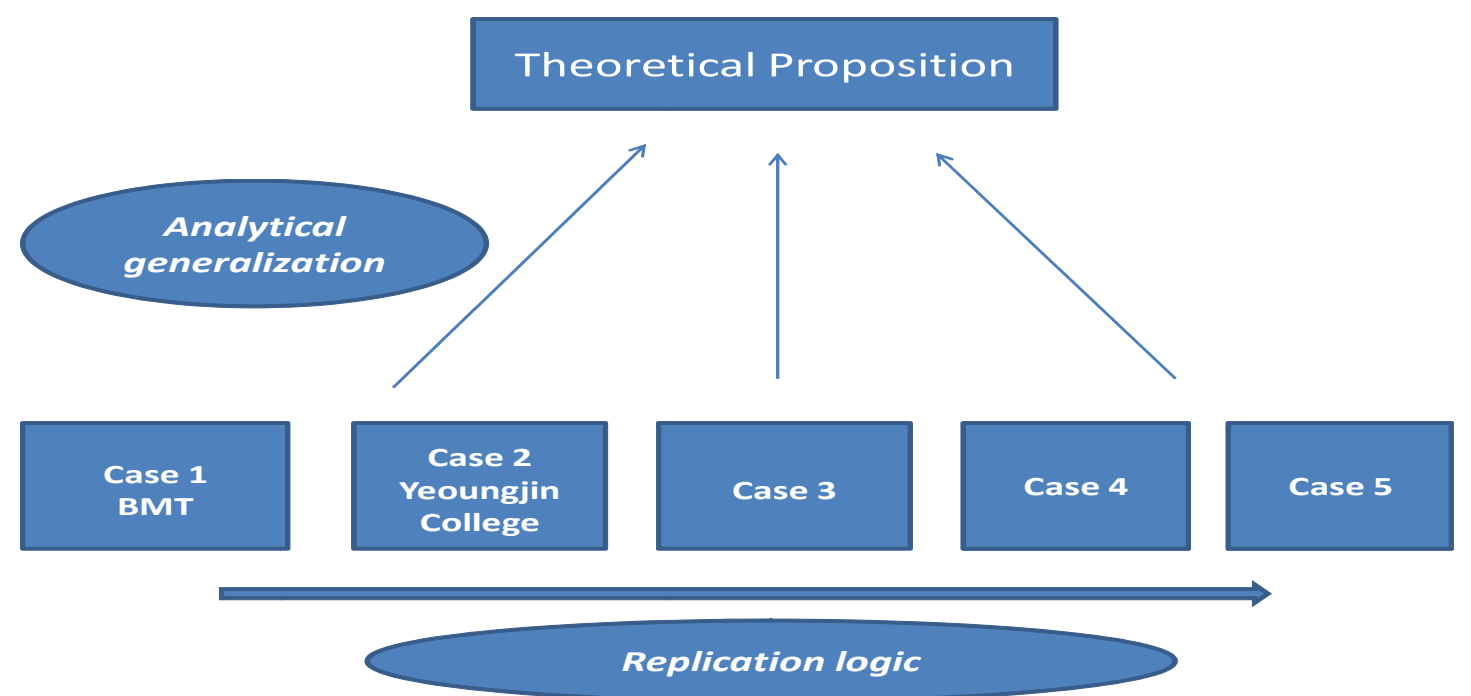

Source: Modified from “Case Study Research”, Yin, 2003

\section{Copyrights}

Copyright for this article is retained by the author(s), with first publication rights granted to the journal.

This is an open-access article distributed under the terms and conditions of the Creative Commons Attribution license (http://creativecommons.org/licenses/by/4.0/). 